\title{
ASSESSMENT OF THE ORGANIC AND INORGANIC FERTILIZERS APPLICATION ON MAIZE/WHEAT PRODUCTION IN CALCAREOUS SOIL
}

\author{
Abd El-Aal, M.H., A.E.A. Shiref and Awadalla, H.A. \\ Soils, Water and Environ. Res. Inst., Agric. Res. Center (ARC), Giza, \\ Egypt.
}

ABSTRACT

Maize and wheat are the most important cereal crops in Egypt. A field experiment was carried out at the Noubaria Farm Agricultural Research Station during summer 2009 followed by winter 2009/2010 for maize and wheat, respectively. This study was conducted to evaluate the impacts of the integrated individual use of sole mineral NPK fertilizers, or combinations of either single type or various mixtures of NPK and compost types. The standard different fertilization treatments were rates of $75 \%$ or $100 \%$ (as a recommended dose by the Ministry of Agriculture and Land Reclamation (Egypt). Maize was grown single cross 10 to study the effect of these treatments and their residual effect on followed wheat (C.V. Sakha 93). The results could be summarized as those due to the case of the above mentioned rates of $100 \%$ and $75 \%$. However, the application of $100 \%$ (NPK) and compost were indicated a better yield of maize grain, stover, wheat grain and straw. Moreover, this preferable rate $100 \%$ has left higher availability percentages of macronutrients in both cases of maize and wheat, as compared to rate of $75 \%$. Significant increase of all parameters i.e., grain and stover yields, macronutrients content and the availability of macronutrients for maize soil, were achieved by the application of the mineral NPK solely. While lower values of this parameters, were recorded when applying any single compost types. On the other hand, the trend for residual effect and the resulting availability of macronutrient content of wheat grains, and straw was greatly enhanced by the addition of any organic manures. Interaction between factors under study, shows that the complementary organic and inorganic fertilizers under the high level was more effective than individual application of either organic or mineral (NPK) fertilizers alone for macronutrients content of maize and wheat grains, as well as in soil after harvesting both crops.

Key words: Compost, NPK mineral fertilizer, calcareous soil, maize, wheat, yield, macronutrients.

\section{INTRODUCTION}

It has known that fertility of soil is also related to soil organic matter content and added organic matter. Fertilizer application can guarantee the high yield of crop, it method to enhance crop yield. There is no doubt that fertilizers play a very active role in increasing crop yield and nutrients availability of wheat and maize (Baloch et al., 2004; Rajput et al., 2004; Ayodele and Omotoso, 2008 and Zhang et al., 2009). Recycling organic wastes such as organic crop residues and animal wastes in agriculture may have a role in decreasing the enormous consumption of chemical fertilizers in Egypt. Chemical fertilizer pollute environment with chemical elements and contaminate ground water with successive uses. The newly reclaimed soils in

Fayoum J. Agric. Res. \& Dev., Vol. 26, No.2, July, 2012 
Egypt are sandy and calcareous soils which are mostly poor in available nutrients. To increase their productivity, organic matter application plays an important role to retain the inorganic elements in complex and chelate forms. In this concern, organic manures are well established for fertilizing plants due to their beneficial effects on the physical-chemical and biological characteristics of the soils worldwide. These in turn influence the growth and increase plants production (Jimenez et al., 2002, Celik et al., 2004, Nardi et al., 2004, Weil and Magdoff, 2004, and Yassen et al., 2010).

Response of crops to applying fertilizer depends on soil organic matter. The quantity of soil organic matter depends on the quantity of organic material which can be introduced into the soil either by natural returns through roots, stubbles, sloughed-off root nodules and root exudates. Also, by artificial application in the form of organic manure which can otherwise be called organic fertilizer (Agboola and Omueti, 1982). Nitrogen, essential to plant growth is taken up by plant from the soil in simple inorganic form, i.e. as nitrate and ammonium. These are released from complex organic compounds by the action of decomposing microorganisms, a process known as mineralization. The amount of nitrogen supplied to a crop after application of manure depends on the interaction of several processes (immobilization, leaching, mineralization, nitrification, volatilization and denitrification), which are markedly affected by manure type, time and rate of application and management (Shepherd, 1993). However, during decomposition of organic matter, organic acids and carbondioxide are formed (Tisdale $\boldsymbol{e t}$ al., 1985) and added organic materials appear to have a solubilizing effect on $\mathrm{Fe}, \mathrm{Al}$ and $\mathrm{Ca}$ phosphate due to the increase in biological activities (Trono, 1986). Nutrient recycling is a dynamic process and it is not easy to assess fertility decline, as it requires long-term monitoring of the soils. (Tripathi and Tuladhar, 2001) mentianed that farmyard manure (FYM) found to be an effective N-source for maize and wheat. Since it may supply sufficient nitrogen in synchrony manure when mixed with compost. If the mineral $\mathrm{N}$ pool in soil is produced too early, it can potentially be lost through leaching and/or denitrification. If released too late, $\mathrm{N}$ application will not benefit the crop and possesses a potential threat to groundwater quality via leaching. (Prasad and Sinha, 2000) stated that, the effect of FYM or FYM + crop residues could substitute 50\% NPK for wheat production and their residual effect was equivalent to $50 \%$ of the recommended dose of NPK as a mineral fertilizer on the yield of succeeding rice crop. Available N, P, S, Zn, Fe, Cu, Mn, $\mathrm{B}$, and Mo in soil increased when different levels of fertilizers were applied along with crop residues and organic manure. The efficiency of applied nutrients by rice and wheat were higher in plots treated with crop residues than that of FYM treated plots. (Bar-Tal et al., 2004) concluded that, large amount of compost was required in the short term to supply the inorganic $\mathrm{N}$ for wheat because of the low net mineralization rate of organic $\mathrm{N}$. They also reported that the main constraint to compost application should be the contents of $\mathrm{P}$, soluble salts, and some hazards elements. (Singh et al., 2011) stated that, the effect combined application of organic manures and inorganic fertilizer increased the dry matter, grain yield, straw yield and NPK uptake by wheat crop. (Fateh $\boldsymbol{e t}$ al., 2009) determined the chemical and manure fertilizer levels and mixture of different ration of chemical and manure together. They declared that fertilization treatments significantly affected forage quantity, quality of artichoke and NPK content in globe artichoke.

Fayoum J. Agric. Res. \& Dev., Vol. 26, No.2, July, 2012 
Therefore, the main objective of this study was to reduce the uses of mineral fertilizers by adding compost to calcareous soil in order to avoid the possible pollution of environment and ground water.

\section{MATERIALS AND METHODS}

A field experiment was carried out at Nubaria Agriculture Research Station Farm during summer season of 2009 for maize (Zea mays L.) followed by winter season of 2009/2010 for wheat (Triticum Vulgare L.), cultivated in calcareous soil under surface irrigation system. Soil surface samples from the layers $(0-20 \mathrm{~cm})$ were taken, air-dried and ground to pass through a $2.0 \mathrm{~mm}$. sieve and thoroughly mixed for analysis. Some physical and chemical properties of soil and composts were analyzed and shown in Table 1. The experimental details are given in Table 2.

A randomized complete block in the split plot design with three replications was conducted. The two factors of the study were $(\mathrm{A})$ two rates of fertilizer treatments (R1 and R2), i.e. 75 and $100 \%$ of the mineral fertilizer from its recommended rates, and 3 and 4 ton/ fed for composts. (B) mineral $\mathrm{N}$ $\mathrm{P} \mathrm{K}$ and / or compost as follows:

1. Mineral fertilizers (NPK) (MF)

2. Compost 1, Com 1 : consists of $25 \%$ farmyard manures, 10 farm wastes and $65 \%$ (rice straw, some activation from bacteria Azotobacter sp. + Azosprillum sp. + Bacillus megatherium sp. + Pseudomonas sp. And some mineral fertilizers ).

3. Compost 2, Com 2: consist of $50 \%$ town refuse and $50 \%$ sewage sludge.

4. Compost 3, Com 3: consist of $60 \%$ farmyard manurers, $15 \%$ chicken manure , and $25 \%$ rice straw.

5. Compost $1+$ Mineral fertilizers [Com. $(1)+\mathrm{MF}]$.

6. Compost $2+$ Mineral fertilizers $[$ Com. $(2)+$ MF].

7. Compost $3+$ Mineral fertilizers [Com. (3) $+\mathrm{MF}]$.

8. Compost $1+$ Compost 2: [Com. (1) + Com. (2)].

9. Compost $1+$ Compost 3: [Com. (1) + Com. (3)].

10. Compost $2+$ Compost 3: [Com. (2) + Com. (3)].

Maize, single cross 10 was sown during the first week of June 2009 on a plot area of $10.5 \mathrm{~m}^{2}$. All the organic materials were incorporated during the land preparation for maize sowing. Nitrogen fertilizer was added as ammonium nitrate $(33.5 \% \mathrm{~N})$ at the rates of 90 or $120 \mathrm{~kg} \mathrm{~N} \mathrm{fed}^{-1}$ in two equal doses; 30 days after planting and 25 days later. Phosphorus fertilizer, in the form of super phosphate $\left(15.5 \% \mathrm{P}_{2} \mathrm{O}_{5}\right)$, was applied at planting at the rates of 23.3 or $31 \mathrm{~kg}$ $\mathrm{P}_{2} \mathrm{O}_{5}$ fed $^{-1}$. Potassium fertilizer was added as potassium sulphate $\left(48 \% \mathrm{~K}_{2} \mathrm{O}\right)$ at the rates of: 36 and $48 \mathrm{~kg} \mathrm{~K}_{2} \mathrm{O}$ fed ${ }^{-1}$ with the second dose of $\mathrm{N}$ fertilizer.

At the end of the experiment (lasting 120 days), soil samples and maize plants were taken, i.e. five random plants per plot from all the treatments, thoroughly washed with tap water followed by distilled water, dried in an oven at $65^{\circ} \mathrm{C}$ for 72 hours, ground and stored for chemical analysis. Wheat was planted during the third week of November 2009, the same plot were used without applied fertilizers to study the residual effect in the soil from previous season (Maize plants experiment). At the end of wheat experiment (lasted 180 days), soil samples and wheat plants were taken, i.e. ten random plants per plot from all the treatments, thoroughly washed with tap water followed by distilled

Fayoum J. Agric. Res. \& Dev., Vol. 26, No.2, July, 2012 
Abd El-Aal, et al.,

water, dried in an oven at $65^{\circ} \mathrm{C}$ for 72 hours and ground in stainless steel mill then stored for chemical analysis.

Soil, compost and plant analysis:

Physical and chemical analyses of both soil and compost were carried out according to (AOAC, 1995). Available $\mathrm{N}^{-\mathrm{NH}_{4}}{ }^{+}$and $\mathrm{N}^{-\mathrm{NO}_{3}}{ }^{-}$were extracted with $\mathrm{KCl}(2 \mathrm{~N})$ and measured by Technician Auto Analyzer according to (Markus et al., 1982). Available macro and micro nutrients in soil samples and compost were extracted with AB-(DTPA), according to Soltanpour and Schwab, (1991). Plant samples were digested using $\left(\mathrm{HClO}_{4}+\mathrm{H}_{2} \mathrm{SO}_{4}\right)$ acids according to the procedure of (Cottenie $\boldsymbol{e t}$ al., 1982). ( $\mathrm{P}$ and $\mathrm{K}$ ) in plant were determined in this extract using Inductively Coupled Plasma (ICP) Spectrometry model JY-Ultima2. Total nitrogen in soil and plant was determined using Kjeldahl method according to (Chapman and Pratt, 1961). $\mathrm{K}$ in plant was determined using flame photometer. Extraction of humus was performed according to the method of (Kononova, 1966).

Table 1: Physical and chemical properties of soil and compost used in the study

\begin{tabular}{|c|c|c|c|c|}
\hline Items & Soil & Com.(1) & Com.(2) & Com.(3) \\
\hline $\begin{array}{l}\text { Coarse sand \% } \\
\text { Fine sand \% } \\
\text { Silt \% } \\
\text { Clay \% } \\
\text { Texture class }\end{array}$ & $\begin{array}{c}42.00 \\
12.00 \\
16.00 \\
30.00 \\
\text { Sandy clay loam }\end{array}$ & $\begin{array}{l}--- \\
--- \\
--- \\
--- \\
---\end{array}$ & $\begin{array}{l}--- \\
--- \\
--- \\
--- \\
---\end{array}$ & $\begin{array}{l}--- \\
--- \\
--- \\
--- \\
---\end{array}$ \\
\hline $\begin{array}{l}\text { Saturation percent } \% \\
\mathrm{CaCO}_{3} \% \\
\mathrm{pH} \text { : In suspension. }(1: 2.5) \text { for } \\
\quad \text { soil, }(1: 10) \text { for compost } \\
\mathrm{EC} \mathrm{dS/m}\end{array}$ & $\begin{array}{l}45.00 \\
31.25 \\
8.10 \\
3.44\end{array}$ & $\begin{array}{c}100 \\
3.31 \\
7.20 \\
8.1\end{array}$ & $\begin{array}{l}74.67 \\
7.74 \\
6.85 \\
21.3\end{array}$ & $\begin{array}{c}92.00 \\
5.83 \\
7.75 \\
10.6\end{array}$ \\
\hline \multicolumn{5}{|c|}{ meq.100g soil or compost } \\
\hline $\begin{array}{l}\mathrm{Ca}^{2+} \\
\mathrm{Mg}^{2+} \\
\mathrm{Na}^{+} \\
\mathrm{K}^{+} \\
\mathrm{CO}_{3}= \\
\mathrm{HCO}_{3}^{-} \\
\mathrm{CL}^{-} \\
\mathrm{SO}_{4}= \\
\end{array}$ & $\begin{array}{c}8.0 \\
6.4 \\
12.2 \\
8.0 \\
0.00 \\
3.2 \\
7.2 \\
24.2\end{array}$ & $\begin{array}{c}20.90 \\
17.30 \\
21.25 \\
18.00 \\
0.00 \\
22.74 \\
39.60 \\
15.51\end{array}$ & $\begin{array}{c}110.85 \\
36.90 \\
95.25 \\
10.05 \\
0.00 \\
61.35 \\
115.35 \\
76.35\end{array}$ & $\begin{array}{c}6.37 \\
16.30 \\
55.38 \\
40.18 \\
0.00 \\
9.41 \\
66.33 \\
42.49\end{array}$ \\
\hline $\begin{array}{l}\text { Humic acid \% } \\
\text { Fulvec acid \% } \\
\text { (CEC) meq. } 100 \mathrm{~g}^{-1}\end{array}$ & $\begin{array}{c}--- \\
--- \\
15.29\end{array}$ & $\begin{array}{l}21.50 \\
11.50 \\
48.40\end{array}$ & $\begin{array}{l}24.50 \\
12.70 \\
32.60\end{array}$ & $\begin{array}{l}26.30 \\
13.03 \\
62.50\end{array}$ \\
\hline Organic matter \% & 1.11 & 32.75 & 33.93 & 35.38 \\
\hline $\begin{array}{l}\text { Organic carbon \% } \\
\text { C:N ratio } \\
\text { Total.N \% }\end{array}$ & $\begin{array}{l}0.645 \\
\ldots \ldots \\
0.12\end{array}$ & $\begin{array}{l}18.99 \\
1: 18 \\
1.05\end{array}$ & $\begin{array}{l}19.68 \\
1: 16 \\
1.20\end{array}$ & $\begin{array}{c}20.52 \\
1: 14 \\
1.40\end{array}$ \\
\hline \multicolumn{5}{|c|}{ Available mg. $\mathrm{kg}^{-1}$} \\
\hline $\begin{array}{l}\mathrm{N} \\
\mathrm{P} \\
\mathrm{K} \\
\mathrm{Fe} \\
\mathrm{Mn} \\
\mathrm{Zn} \\
\mathrm{Cu}\end{array}$ & $\begin{array}{c}23.07 \\
9.79 \\
180.46 \\
12.29 \\
8.29 \\
0.85 \\
1.42\end{array}$ & $\begin{array}{l}2179 \\
22.23 \\
6452 \\
111.8 \\
82.75 \\
28.99 \\
4.358\end{array}$ & $\begin{array}{c}5955 \\
55.56 \\
1134 \\
308.4 \\
16.65 \\
79.02 \\
8.488\end{array}$ & $\begin{array}{l}3430 \\
56.94 \\
17204 \\
343.2 \\
35.37 \\
45.00 \\
4.456\end{array}$ \\
\hline
\end{tabular}

Fayoum J. Agric. Res. \& Dev., Vol. 26, No.2, July, 2012 
ASSESSMENT OF THE ORGANIC AND INORGANIC

Table 2. Treatment details for the experiment

\begin{tabular}{|c|c|c|}
\hline \multirow[b]{2}{*}{ Treatments } & \multicolumn{2}{|c|}{ Fertilizer levels } \\
\hline & $75 \%(\mathrm{R} 1)$ & $100 \%(\mathrm{R} 2)$ \\
\hline $\mathrm{MF}$ & $90: 22.5: 36(\mathrm{NPK})$ & 120:30:48 (NPK) \\
\hline Compost 1 & $3 \mathrm{t} / \mathrm{fed}$ & $4 \mathrm{t} / \mathrm{fed}$ \\
\hline Compost 2 & $3 \mathrm{t} / \mathrm{fed}$. & $4 \mathrm{t} / \mathrm{fed}$ \\
\hline Compost 3 & $3 \mathrm{t} / \mathrm{fed}$. & $4 \mathrm{t} / \mathrm{fed}$. \\
\hline $0.5 \mathrm{MF}+0.5$ Com. 1 & 45:11.25:18 (NPK) + 1.5 t/fed. (Com. 1$)$ & 60:15:24 (NPK) + 2 t/fed. (Com.1) \\
\hline $0.5 \mathrm{MF}+0.5$ Com. 2 & 45:11.25:18 (NPK) + 1.5 t/fed. (Com. 2) & 60:15:24 (NPK) + 2 t/fed. (Com. 2$)$ \\
\hline $0.5 \mathrm{MF}+0.5 \mathrm{Com} .3$ & 45:11.25:18 (NPK) + 1.5 t/fed. (Com. 3) & $60: 15: 24(\mathrm{NPK})+2 \mathrm{t} / \mathrm{fed} .(\mathrm{Com} .3)$ \\
\hline 0.5 Com. $1+0.5$ Com. 2 & $1.5 \mathrm{t} / \mathrm{fed} .(\mathrm{Com} .1)+1.5 \mathrm{t} / \mathrm{fed}$. (Com. 2) & 2 t/fed. (Co 1) +2 t/fed. (Com.2) \\
\hline 0.5 Com. $1+0.5$ Com. 3 & $1.5 \mathrm{t} /$ fed. (Com. 1) +1.5 t/fed. (Com. 3) & $2 \mathrm{t} /$ fed. (Co 1) $+2 \mathrm{t} /$ fed. (Com.3) \\
\hline 0.5 Com. $2+0.5$ Com. 3 & $1.5 \mathrm{t} / \mathrm{fed} .($ Com. 2$)+1.5 \mathrm{t} / \mathrm{fed}$. (Com. 3) & $2 \mathrm{t} / \mathrm{fed}$. (Co 2) $+2 \mathrm{t} / \mathrm{fed}$. (Com.3) \\
\hline
\end{tabular}

\section{Statistical analysis:}

The data were subjected to statistical analysis according to the randomized complete block design. Differences between treatment means were compared at $\mathrm{P}=5 \%$ with ANOVA in order to find the statistically significant differences and then LSDs were used to compare the plots (Snedecor and Cochran, 1976). The statistical analysis of the data was realized using the Statistical Analysis System (SAS) program SAS, (1994).

\section{RESULTS AND DISCUSSION \\ Yield of maize followed by wheat plants}

Data presented in Table 3 show the maize grain \&stover yields as well as wheat grain \& straw yields as influenced by different fertilizer treatments. As a general pattern, the highest level of organic and inorganic fertilizers gave high significant values of maize grain \& stover yields compared with the lowest one. While, the residual effect on wheat grain yield was significantly increased with the high level of organic and inorganic fertilizers compared to low level application. On the other hand, straw yield was not affected by the applied organic and inorganic fertilizers. These results may be attributed to the high rates of organic and inorganic fertilizers equal the recommended doses of maize plants were sufficient to this plant under study.

The treatment of $100 \%$ inorganic (mineral) fertilizer sole or $50 \%$ mineral + compost (3) gave the highest significant values of grain and stover maize yields, while, the treatment of compost (2) alone achieved the lowest significant ones. The superiority of compost 3 on grain and stover yields of maize may by due to its high content of total nitrogen, humic acid and fulvec acid (Table, 1). While the negative effect of compost 2 on maize grain and stover yield could be attributed to its content of $50 \%$ town refuse which increased its Salinty ( about $21.3 \mathrm{dsm}-1$, Table 1 ). On the other hand, results of the residual effect of such fertilizers on wheat plant reveal that the treatment of compost (2) give the best significant values of grain and straw yield of wheat after maize. Meanwhile, the lowest ones were recorded when sole mineral fertilizer $100 \%$ was applied. These results may be due to utilize from mineral fertilizer is completed in the first season only, while organic fertilizer so appears in the second one looked for slow release of organic matter and availability of its nutrients favored to yield increase in the second season. Nutrients contained in organic manures are released more slowly and are stored

Fayoum J. Agric. Res. \& Dev., Vol. 26, No.2, July, 2012 
for a longer time in the soil, thereby ensuring a long residual effect (Sharma and Mittra, 1991). Improvement of environmental conditions and public health as well as the need to reduce costs of fertilizing crops are also important reasons for advocating increased use of organic materials (Seifritz, 1982). Application of organic manures also improves the soil microbial properties (Belay et al., 2001). High and sustained crop yield could be obtained with judicious and balanced NPK fertilization combined with organic matter amendments (Makinde et al., 2001; Bayu et al., 2006; Ayoola and Makinde 2007). Maize performed best in terms of growth and yield with complementary application of mixture inorganic and organic fertilizers. This is in agreement with the findings of (Titiloye, 1982) who reported that the most satisfactory method of increasing maize yield was by judicious combination of organic wastes and inorganic fertilizers.

Table 3. Maize and wheat yields as affected by organic and inorganic fertilizers under two levels of application rates

\begin{tabular}{|c|c|c|c|c|c|c|}
\hline \multicolumn{7}{|c|}{ Maize plant } \\
\hline Treatments ( B ) & \multicolumn{3}{|c|}{ Grains yield $\mathrm{kg} /$ fed. } & \multicolumn{3}{|c|}{ Stover yield kg/ fed. } \\
\hline & $\mathbf{R 1}$ & $\mathbf{R 2}$ & $\operatorname{Mean}(\mathrm{A})$ & R 1 & $\mathbf{R 2}$ & Mean \\
\hline MF & 2391 & 2659 & 2525 & 3431 & 3816 & 3624 \\
\hline Compost 1 & 2126 & 2341 & 2234 & 3050 & 3360 & 3205 \\
\hline Compost 2 & 1950 & 2352 & 2151 & 2800 & 3376 & 3088 \\
\hline Compost 3 & 2299 & 2501 & 2400 & 3299 & 3628 & 3464 \\
\hline $0.5 \mathrm{MF}+0.5$ Com. 1 & 2264 & 2470 & 2367 & 3248 & 3545 & 3397 \\
\hline $0.5 \mathrm{MF}+0.5$ Com. 2 & 2183 & 2516 & 2349 & 3132 & 3610 & 3371 \\
\hline $0.5 \mathrm{MF}+0.5$ Com. 3 & 2445 & 2619 & 2532 & 3509 & 3759 & 3634 \\
\hline 0.5 Com. $1+0.5$ Com. 2 & 2252 & 2229 & 2240 & 3231 & 3199 & 3215 \\
\hline 0.5 Com $.1+0.5$ Com. 3 & 2296 & 2248 & 2272 & 3295 & 3226 & 3261 \\
\hline 0.5 Com $.2+0.5$ Com .3 & 2327 & 2336 & 2331 & 3339 & 3352 & 3346 \\
\hline Mean & 2253 & $2427^{*}$ & & \multicolumn{3}{|c|}{$3487 *$} \\
\hline LSD at 0.05 & \multicolumn{3}{|c|}{$\begin{array}{l}B: 35 \\
A B: 49\end{array}$} & \multicolumn{3}{|c|}{$\begin{array}{l}56 \\
79 \\
\end{array}$} \\
\hline \multicolumn{7}{|c|}{ Wheat plant } \\
\hline & \multicolumn{3}{|c|}{ Grain yield kg/ fed. } & \multicolumn{3}{|c|}{ Straw yield kg/ fed. } \\
\hline $\mathrm{MF}$ & 787.7 & 826.7 & 807.2 & 2009 & 2109 & 2059 \\
\hline Compost 1 & 1264 & 1277 & 1271 & 3222 & 3255 & 3239 \\
\hline Compost 2 & 1378 & 1492 & 1435 & 3512 & 3802 & 3657 \\
\hline Compost 3 & 1284 & 1453 & 1369 & 3273 & 3702 & 3487 \\
\hline $0.5 \mathrm{MF}+0.5$ Com. 1 & 1247 & 1307 & 1277 & 3177 & 3331 & 3254 \\
\hline $0.5 \mathrm{MF}+0.5$ Com. 2 & 1133 & 1226 & 1179 & 2887 & 3125 & 3006 \\
\hline $0.5 \mathrm{MF}+0.5$ Com. 3 & 1364 & 1381 & 1373 & 3475 & 3521 & 3498 \\
\hline 0.5 Com. $1+0.5$ Com. 2 & 1218 & 1263 & 1241 & 3105 & 3219 & 3162 \\
\hline 0.5 Com. $1+0.5$ Com. 3 & 1192 & 1253 & 1222 & 3037 & 3192 & 3114 \\
\hline 0.5 Com. $.2+0.5$ Com. 3 & 1252 & 1294 & 1273 & 3190 & 3299 & 3244 \\
\hline Mean & 1219 & $1277^{*}$ & & 3088 & 3255 & \\
\hline LSD at 0.05 & & $\begin{array}{l}3: 0.31 \\
B: 0.44\end{array}$ & & & $\begin{array}{l}0.2 \\
0.3\end{array}$ & \\
\hline
\end{tabular}

Fayoum J. Agric. Res. \& Dev., Vol. 26, No.2, July, 2012 
Concerning the effect of interacted factors under study, data in Table 3 reveal that the treatment of $100 \%$ inorganic (mineral) fertilizer sole or/ and 50\% mineral + compost (3) with the high level from fertilizer achieved a remarkable significant increase of grain and stover maize compared to the other treatments. Whereas, the lowest one were obtained when compost (2) alone under the low level of fertilizer was practiced. On the contrary, the highest significant values for grain and straw yields of wheat plant were observed by compost (2) alone under the high level of fertilizer. Meanwhile, the lowest one was recorded when sole mineral fertilizer with the low level of fertilizer was applied. High maize and Wheat grains yields resulted from addition compost may be attributed to the composition residues contain large amount of $\mathrm{Fe}, \mathrm{Mn}, \mathrm{Zn}$, and $\mathrm{Cu}$ than the other sources. The results are in agreement with those achieved by (Korim $\boldsymbol{e t}$ al., 2009) who reported that consequently the concentration of Fe, $\mathrm{Mn}, \mathrm{Zn}$, and $\mathrm{Cu}$ in grains of maize and grains of wheat were increased the yields of maize grains and stalk as well as Wheat grains and straw (kg.fed $\left.{ }^{-1}\right)$ gave highest significant increases. These results suggest that sole application of either compost or NPK is not advisable as none of them produced maximum grains

\section{Macronutrients content in grains of maize and wheat.}

Generally, the data in Table 4 reveal that N, P and K contents of maize grains were significantly increased when high level of fertilizer was added compared to the lower one. While, the residual effect of two organic and inorganic fertilizer levels on $\mathrm{P}$ and $\mathrm{K}$ contents of wheat grains show the same trend as maize. On the other hand, the low level gave highly significant increases on $\mathrm{N}$ content in wheat grain as compared with the high level.

As a general view, data illustrated in Table 4 indicated that the treatment of mineral $\mathrm{N}$ fertilization alone at the rate of $120 \mathrm{~kg} / \mathrm{fed}$. significantly surpassed the other treatments for NP and K contents of maize grains. While, the lowest values of $\mathrm{N}$ content was recorded when compost (1) alone was used. On the other hand, applying compost 1 and/or 2 gave the lowest significant values of $\mathrm{P}$ content in maize grain but $\mathrm{K}$ content of maize grains was recorded by adding compost (2) alone. On the opposite, the highest values of $\mathrm{N}$ content of wheat grains growing after maize plant was recorded when 100\% inorganic (mineral) fertilizer was applied in combined with $50 \%$ compost 3 at $75 \%$ from its recomneded rate, while, the treatment of 50\% mineral + compost (3) at higher rate gave the highest significant value of $\mathrm{P}$ content. On the other hand, the highest values of $\mathrm{K}$ content in wheat grain was obtained when compost (3) alone was added. The obtained results may be attributed to the higher nutrients content go in agreement with those of higher produced yields resulted from the same treatments. (Ayoola and Makinde, 2007) concluded that the maize yields with complementary inorganic + organic fertilizers and with sole inorganic fertilizer treatment were comparable because nutrients were readily released from the inorganic fertilizer and maize being an aggressive feeder, was able to utilize it for its growth and yield. Maize did not seem to benefit much from organic fertilizer probably because of low mineralization of nutrients from that source. (Adeniyan and Ojeniyi, 2005) have also reported a higher yield of maize from a combined use of NPK fertilizer and poultry manure than from sole applications.

Fayoum J. Agric. Res. \& Dev., Vol. 26, No.2, July, 2012 
Table 4. N, $P$ and $K$ contents in grains of maize and wheat as affected by organic and inorganic fertilizers under two levels of application

\begin{tabular}{|c|c|c|c|c|c|c|c|c|c|}
\hline \multicolumn{10}{|c|}{ Grains of maize plant } \\
\hline \multirow[t]{2}{*}{ Treatments } & \multicolumn{3}{|c|}{ N-Uptake kg/fed. } & \multicolumn{3}{|c|}{ P- Uptake kg/fed. } & \multicolumn{3}{|c|}{ K- Uptake kg/fed. } \\
\hline & R 1 & R 2 & Mean & R 1 & R 2 & Mean & $\mathbf{R} 1$ & R 2 & Mean \\
\hline $\mathrm{MF}$ & 32.30 & 39.64 & 35.97 & 10.02 & 10.27 & 10.15 & 14.71 & 16.98 & 15.84 \\
\hline Compost 1 & 11.50 & 17.11 & 14.31 & 4.642 & 5.457 & 5.049 & 8.421 & 10.81 & 9.615 \\
\hline Compost 2 & 18.52 & 24.95 & 21.74 & 4.514 & 5.627 & 5.071 & 6.499 & 8.246 & 7.372 \\
\hline Compost 3 & 18.64 & 20.88 & 19.76 & 5.567 & 6.635 & 6.101 & 12.10 & 14.07 & 13.09 \\
\hline $0.5 \mathrm{MF}+0.5$ Com. 1 & 23.56 & 31.39 & 27.48 & 7.068 & 7.828 & 7.448 & 11.80 & 13.46 & 12.63 \\
\hline $0.5 \mathrm{MF}+0.5$ Com. 2 & 22.50 & 31.21 & 26.86 & 7.201 & 8.554 & 7.878 & 8.476 & 10.95 & 9.715 \\
\hline $0.5 \mathrm{MF}+0.5$ Com. 3 & 24.47 & 28.31 & 26.39 & 9.345 & 10.20 & 9.770 & 14.47 & 15.70 & 15.09 \\
\hline 0.5 Com. $1+0.5$ Com. 2 & 20.06 & 21.19 & 20.63 & 5.996 & 5.419 & 5.708 & 8.216 & 8.832 & 8.524 \\
\hline 0.5 Com $.1+0.5$ Com. 3 & 15.63 & 18.00 & 16.82 & 6.007 & 5.819 & 5.913 & 11.61 & 12.07 & 11.84 \\
\hline 0.5 Com $.2+0.5$ Com .3 & 19.33 & 20.81 & 20.07 & 6.983 & 6.190 & 6.587 & 10.13 & 11.45 & 10.79 \\
\hline Mean & 20.65 & $25.35^{*}$ & & 6.74 & $7.20 *$ & & 10.64 & $12.26^{*}$ & \\
\hline \multirow[t]{2}{*}{ LSD at 0.05} & \multicolumn{3}{|c|}{ B: 0.42} & \multicolumn{3}{|c|}{0.153} & \multicolumn{3}{|c|}{0.157} \\
\hline & \multicolumn{3}{|c|}{$A B: 0.59$} & \multicolumn{3}{|c|}{0.216} & \multicolumn{3}{|c|}{0.222} \\
\hline
\end{tabular}

Grains of wheat plant

\begin{tabular}{|c|c|c|c|c|c|c|c|c|c|}
\hline & \multicolumn{3}{|c|}{ N- Uptake kg/fed. } & \multicolumn{3}{|c|}{ P- Uptake kg/fed. } & \multicolumn{3}{|c|}{ K- Uptake kg/fed. } \\
\hline MF & 9.298 & 8.355 & 8.826 & 2.095 & 2.315 & 2.205 & 10.45 & 12.28 & 11.36 \\
\hline Compost 1 & 14.92 & 13.54 & 14.23 & 3.512 & 3.771 & 3.641 & 18.35 & 22.88 & 20.62 \\
\hline Compost 2 & 22.05 & 21.09 & 21.57 & 4.380 & 4.739 & 4.559 & 19.19 & 23.21 & 21.20 \\
\hline Compost 3 & 16.70 & 18.30 & 17.50 & 4.191 & 4.746 & 4.469 & 25.93 & 36.23 & 31.08 \\
\hline $0.5 \mathrm{MF}+0.5$ Com. 1 & 20.93 & 19.73 & 20.33 & 3.326 & 3.820 & 3.573 & 19.41 & 23.92 & 21.66 \\
\hline $0.5 \mathrm{MF}+0.5$ Com. 2 & 18.80 & 18.51 & 18.66 & 3.741 & 4.177 & 3.959 & 15.92 & 19.57 & 17.75 \\
\hline $0.5 \mathrm{MF}+0.5$ Com. 3 & 22.09 & 20.44 & 21.27 & 4.785 & 4.971 & 4.878 & 26.02 & 28.52 & 27.27 \\
\hline 0.5 Com. $1+0.5$ Com. 2 & 17.05 & 16.67 & 16.86 & 3.419 & 3.770 & 3.594 & 17.06 & 21.14 & 19.10 \\
\hline 0.5 Com. $1+0.5$ Com. 3 & 14.30 & 13.65 & 13.98 & 3.506 & 3.828 & 3.667 & 21.06 & 23.05 & 22.05 \\
\hline 0.5 Com $.2+0.5$ Com .3 & 19.65 & 17.35 & 18.50 & 3.762 & 4.033 & 3.898 & 22.94 & 26.68 & 24.81 \\
\hline Mean & $17.58 *$ & 16.76 & & 3.671 & $4.017 *$ & & 19.63 & $23.75^{*}$ & \\
\hline LSD at 0.05 & \multicolumn{3}{|c|}{ B: 0.24} & \multicolumn{3}{|c|}{0.037} & \multicolumn{2}{|r|}{0.52} & \\
\hline
\end{tabular}

With regard to the interaction between factors, the treatment of sole mineral fertilizer under the high rates gave the highest significant values of $\mathrm{N}, \mathrm{P}$ and $\mathrm{K}$ contents of maize grains while, the lowest significant value of $\mathrm{N}$ content of grains of maize was recorded when compost (1) at low level. Whereas, compost (1) and /or compost (2) under low level the low value of P content of maize grains, also, data reveal that the lowest value of $\mathrm{K}$ content of maize grains was observed when compost (2) under low level of fertilizer was applied. On the contrary, in most cases, the treatment of sole mineral fertilizer at low level of fertilizer gave the lowest values of N, P and K content of wheat grains sowing followed by maize plant. Also, data reveal that the highest value of $\mathrm{N}$ content in wheat grains was recorded when compost (2) alone or 50\% mineral + compost (3) under low level of fertilizer were added. Meanwhile, 50\% mineral + compost (3) under high level gave the highest value of $\mathrm{P}$ content in wheat grains. On the other hand, the best value of $\mathrm{K}$ content was obtained by adding compost (3) alone at high level of fertilizer.. This finding agrees with (Rehman et al., 2010) who found that the FYM and NPK used in combination improved

Fayoum J. Agric. Res. \& Dev., Vol. 26, No.2, July, 2012 
grain yield by increasing tillers $\mathrm{m}^{-2}$, early plant vigor, spikes $\mathrm{m}^{2}$ and biomass yield.

\section{Macronutrients content of maize stover \& wheat straw}

Data presented in Table 5 illustrated that the $\mathrm{N}, \mathrm{P}$ and $\mathrm{K}$ contents in maize stover and wheat straw were significantly increased by adding the high level of either organic or mineral fertilizers compared to the lower one.

Regarding the effect of organic and inorganic fertilizers on N, P and K contents in maize stover and wheat straw, results show that, the treatment of sole mineral fertilizer significantly surpassed in $\mathrm{N}$ and $\mathrm{K}$ contents of maize stover. Whereas, the treatment of sole mineral fertilize, $50 \%$ mineral + compost (3) or 50\% mineral + compost (2) gave the highest value of $\mathrm{P}$ content in maize stover. On the other hand, the lowest value of $\mathrm{N}$ content in maize stover was recorded when compost (1) alone was applied, also, P content was significantly decreased by adding any treatment of compost (1) alone,50\% mineral + compost (1), $50 \%$ from compost (1) $+50 \%$ from compost (2), $50 \%$ from compost (1) $+50 \%$ from compost (3) and $50 \%$ from compost (2) $+50 \%$ from compost (3). While, $\mathrm{K}$ content was significantly decreased when compost (2) alone was added. On the contrary, the highest significant value of $\mathrm{N}$ content of wheat straw was observed when $50 \%$ mineral + compost (1) was practiced, meanwhile, $\mathrm{P}$ content was increased significantly by adding the treatment of $50 \%$ mineral + compost (3). Also, results show that the highest significant value of $\mathrm{K}$ content was recorded when the treatment of compost (3) alone was added. On the other hand, the lowest significant values of N, P and $\mathrm{K}$ contents of wheat straw were recorded when sole application of mineral fertilizer was added. These findings are in harmony with those obtained by (Shawer, 2003) who found that mixing organic and chemical fertilizers up to $25 \%$ from recommended $\mathrm{N}$ dose gave the best results in yield and nutrients uptake.

With respect to the effect of the interaction between factors on $\mathrm{N}, \mathrm{P}$ and $\mathrm{K}$ contents of maize stover and wheat straw, results show that the $\mathrm{N}$ content of maize stover was significantly increased by adding mineral fertilizer at the high level, while the lowest one was obtained when compost (3) alone under the low level fertilizer was applied. The highest value of $\mathrm{P}$ content in maize stover was recorded when mineral fertilizer alone, $50 \%$ mineral + compost (2) or $50 \%$ mineral + compost (3) at the high level of fertilizer were added. Meanwhile, sole application of organic fertilizer and /or half quantity of mineral fertilizer under both levels of mineral fertilizer gave the lowest value of the $\mathrm{P}$ content in maize stover. On the other hand, the treatment of mineral fertilizer alone at high level significantly surpassed of $\mathrm{K}$ content in maize stover, while, it was significantly decreased by adding compost (2) alone at low level of fertilizer. On the opposite trend, the treatment of sole mineral fertilizer under the low level of fertilizer gave the lowest values of N, P and K contents of wheat straw which was sown after maize plant. Whereas, the highest value of $\mathrm{N}$ content was obtained when $50 \%$ mineral + compost (1) at high level of fertilizer was added, meanwhile, the treatment of $50 \%$ mineral + compost (3) at low level of fertilizer gave the lowest value of $\mathrm{P}$ content. Also results reveal that the lowest value of K content was observed when used compost (3) alone under high level. In this respect, (Shah et al., 2009) found that the integrated use of organic and inorganic nitrogen performed better than the use of organic and inorganic nitrogen sources alone in terms of improving yields of wheat. Shah et al., (2010) concluded that the integrated use of mineral $\mathrm{N}$ source (urea) and organic

Fayoum J. Agric. Res. \& Dev., Vol. 26, No.2, July, 2012 
while, the treatment of sole application of mineral fertilizer gave the lowest values of the same ones. These results may be due to the organic fertilizer contain nutrients (Table, 1) which slowly released for plant growth in followed seasons and save soils from pollution in second season.

Regarding to the interaction between studied factors on soil available $\mathrm{NO}_{3}$ and $\mathrm{NH}_{4}$ after harvesting maize and wheat plants, results in Table 6 show that for soil after maize harvesting, the highest value of $\mathrm{NH} 4$ was recorded when sole application of mineral fertilizer at the high level was practiced, while the lowest one was obtained by adding compost (1) alone under the low level. Whereas, available $\mathrm{NO}_{3}$ was significantly increased by adding mineral fertilizer alone under the low level after harvesting maize plant, meanwhile, the lowest one was observed when $50 \%$ mineral fertilizer + compost (3) at low level was added. For soil analysis after harvesting wheat plant, available $\mathrm{NH}_{4}$ significantly increased when compost (2) alone at the low level of fertilizer, while, the lowest one was obtained by mineral fertilizer alone under the high level of fertilizer. Concerning available $\mathrm{NO}_{3}$ after harvesting wheat plant, the treatment of compost (2) alone under the high level of fertilizer gave the best significant value, whereas, the lowest ones were recorded when mineral fertilizer at low level or $50 \%$ mineral fertilizer + compost (3) under the high level of fertilizer was added. This behavior of $\mathrm{N}$ may be attributed to net immobilization of $\mathrm{N}$ at the first season followed by net mineralization at the second one by the microbial action. These results are in agreement with those obtained by (Bar-Tal et al., 2004). Complementary use of organic manure and mineral fertilizers has been proved to be a sound soil fertility management strategy in many countries of the world (Lombin et al., 1991).

\section{Available $P$ and $K$ in soil after harvesting maize followed by wheat}

Data presented in Table 7 show that the highest mean values of soil available $\mathrm{P}$ and $\mathrm{K}$ after harvesting of maize and wheat plants were obtained when the high level of fertilizer compared to the lowest ones. For soil analysis after harvesting maize plant, available $\mathrm{P}$ and $\mathrm{K}$ were significantly increased by adding mineral fertilizer alone, while, the lowest value of available $\mathrm{P}$ was recorded when $50 \%$ mineral fertilizer + compost (1) was applied. On the other hand, the treatment of compost (2) alone had the lowest value of available K after harvesting maize plant. On the contrary that the lowest values of the available $\mathrm{P}$ and $\mathrm{K}$ after harvesting wheat plant were obtained when mineral fertilizer alone were added. Whereas, the highest value of available $\mathrm{P}$ was observed when $50 \%$ mineral fertilizer + compost (3) was practiced, while, the treatment of compost (2) + compost (3) showed the highest available $\mathrm{K}$ after harvesting wheat plant. Using the compost or mineral may become a suitable solution for reducing the heavy use of non-friendly chemical fertilizers.

Fayoum J. Agric. Res. \& Dev., Vol. 26, No.2, July, 2012 
Table 7. Available $P$ and $\mathrm{K}_{\mathrm{mg}} \mathrm{kg}^{-1}$ of soil after harvesting maize followed by wheat as affected by organic and inorganic nitrogen fertilizers under two levels of application rates

\begin{tabular}{|c|c|c|c|c|c|c|}
\hline \multirow[t]{2}{*}{ Treatments } & \multicolumn{3}{|c|}{ P of maize soil } & \multicolumn{3}{|c|}{ K of maize soil } \\
\hline & R1 & R 2 & Mean & R 1 & R 2 & Mean \\
\hline MF & 12.67 & 24.57 & 18.62 & 680.3 & 727.3 & 703.8 \\
\hline Compost 1 & 7.291 & 10.51 & 8.901 & 396.2 & 414.5 & 405.3 \\
\hline Compost 2 & 9.810 & 11.85 & 10.83 & 380.6 & 391.0 & 385.8 \\
\hline Compost 3 & 10.14 & 13.75 & 11.94 & 477.0 & 539.6 & 508.3 \\
\hline $0.5 \mathrm{MF}+0.5$ Com. 1 & 7.723 & 8.998 & 8.360 & 453.6 & 500.5 & 477.0 \\
\hline $0.5 \mathrm{MF}+0.5$ Com. 2 & 10.17 & 18.22 & 14.19 & 406.6 & 457.2 & 431.9 \\
\hline $0.5 \mathrm{MF}+0.5$ Com. 3 & 12.52 & 19.41 & 15.97 & 398.8 & 543.5 & 471.2 \\
\hline 0.5 Com. $1+0.5$ Com. 2 & 8.143 & 10.81 & 9.476 & 391.0 & 396.2 & 393.6 \\
\hline 0.5 Com. $1+0.5$ Com 3 & 8.684 & 11.05 & 9.867 & 437.9 & 484.8 & 461.4 \\
\hline 0.5 Com $.2+0.5$ Com 3 & 9.770 & 11.08 & 10.43 & 437.9 & 469.2 & 453.6 \\
\hline Mean & 9.692 & $14.025^{*}$ & & 446.00 & 492.37 & \\
\hline \multirow[t]{3}{*}{ LSD at 0.05} & \multicolumn{3}{|c|}{ B: 0.210} & \multicolumn{3}{|c|}{0.20} \\
\hline & \multicolumn{3}{|c|}{ AB: 0.296} & \multicolumn{3}{|c|}{0.28} \\
\hline & \multicolumn{3}{|c|}{ P of wheat soil } & \multicolumn{3}{|c|}{ K of wheat soil } \\
\hline $\mathrm{MF}$ & 8.370 & 9.850 & 9.110 & 281.5 & 383.2 & 332.4 \\
\hline Compost 1 & 9.219 & 11.01 & 10.11 & 401.8 & 406.6 & 404.2 \\
\hline Compost 2 & 10.62 & 11.99 & 11.31 & 285.4 & 401.4 & 343.4 \\
\hline Compost 3 & 10.67 & 12.10 & 11.39 & 492.7 & 563.0 & 527.8 \\
\hline $0.5 \mathrm{MF}+0.5$ Com. 1 & 8.985 & 11.01 & 9.999 & 393.6 & 408.6 & 401.1 \\
\hline $0.5 \mathrm{MF}+0.5$ Com. 2 & 11.83 & 12.84 & 12.34 & 367.5 & 422.3 & 394.9 \\
\hline $0.5 \mathrm{MF}+0.5$ Com. 3 & 12.46 & 13.98 & 13.22 & 461.4 & 477.0 & 469.2 \\
\hline 0.5 Com. $1+0.5$ Com .2 & 9.554 & 11.11 & 10.33 & 383.2 & 453.6 & 418.4 \\
\hline 0.5 Com. $1+0.5$ Com 3 & 9.572 & 11.50 & 10.54 & 406.6 & 430.1 & 418.4 \\
\hline 0.5 Com. $2+0.5$ Com 3 & 9.777 & 11.61 & 10.69 & 445.7 & 613.9 & 529.8 \\
\hline Mean & $10.106^{*}$ & 11.70 & & 391.95 & $455.97 *$ & \\
\hline \multirow[t]{2}{*}{ LSD at 0.05} & \multirow{2}{*}{\multicolumn{3}{|c|}{$\begin{array}{c}\text { B: } 0.209 \\
\text { AB: } 0.296\end{array}$}} & \multicolumn{3}{|c|}{0.20} \\
\hline & & & & \multicolumn{3}{|c|}{0.28} \\
\hline
\end{tabular}

The variation in available $\mathrm{P}$ concentration throughout the growing season of maize and wheat, especially at higher rates indicates that the application of sufficient organic nitrogen sources to meet $\mathrm{N}$ demands as well as the mineral NPK fertilizers may resulted in accumulation of excess $\mathrm{P}$ in the soil after maize. However, it decreased in the soil after wheat may be due to the plant consumption, movement to the deeper layer, or precipitation with $\mathrm{CaCO}_{3}$ or iron oxides in the soil. These results are in agreement with those obtained by (Bar-Tal et al., 2004) who reported that the main constraint to compost application should be the contents of $\mathrm{P}$, soluble salts, and some hazardous elements. 

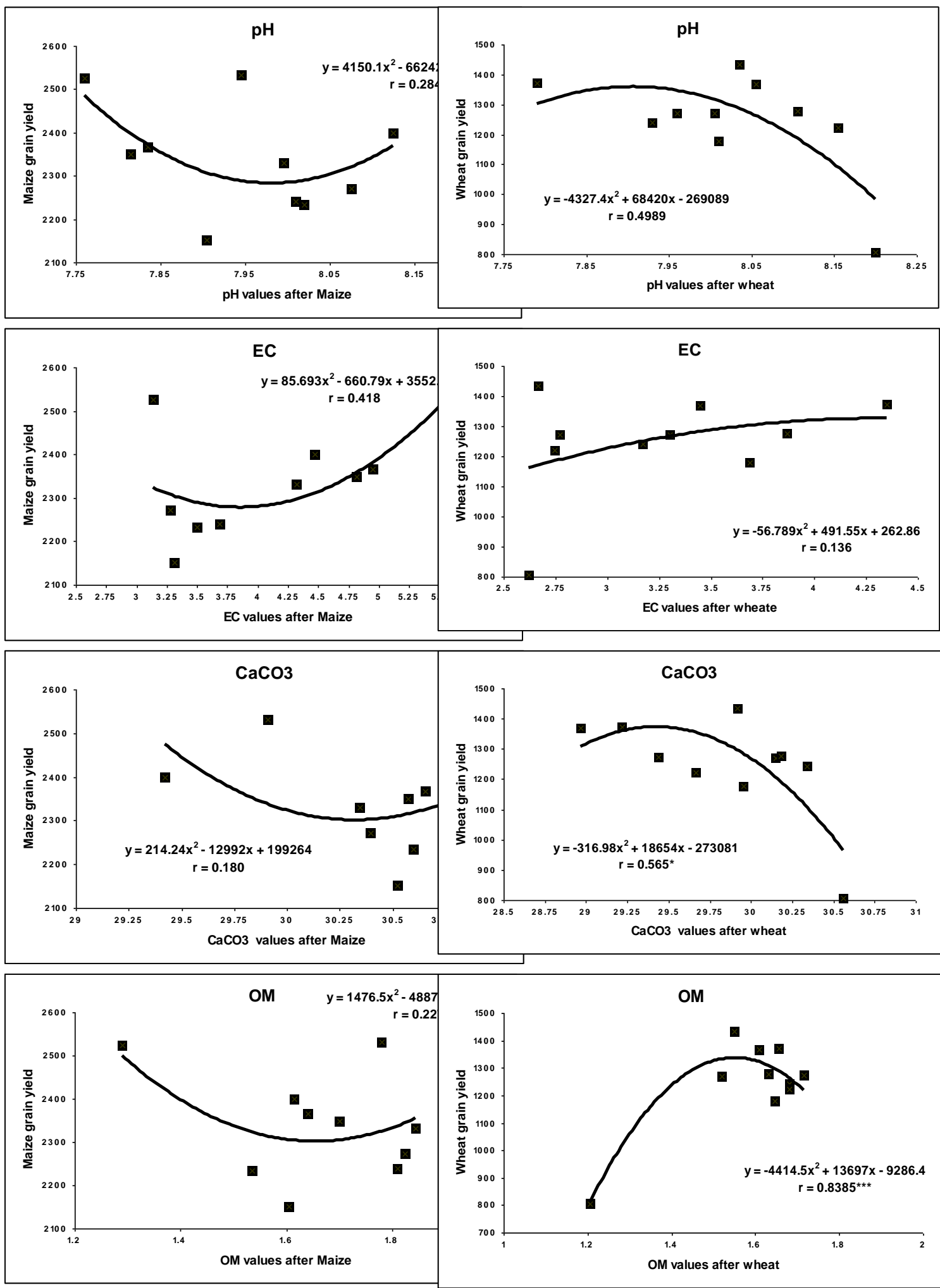

Figure 1. Correlation coefficient values between some chemical properties values for maize and wheat grains together with the corresponding equations.

Fayoum J. Agric. Res. \& Dev., Vol. 26, No.2, July, 2012 
Relationship between some soil chemical properties and maize and wheat grains in calcareous soil after harvesting

Data of $\mathrm{pH}, \mathrm{EC}, \mathrm{CaCO}_{3}$ and organic matter $(\mathrm{OM})$ were measured after harvesting both maize and wheat plants grown in calcareous soil; show that, there no significant differences among productivity of maize \& wheat grains and such parameters under study with two exception on soil organic matter and calcium carbonate after wheat harvesting as illustrated in Figure 1. which shows a positive relationship between both organic matter \& calcium carbonate values and wheat grains yield. Trend lines were fitted to the scattered points using linear, logarithmic, power, exponential and $2^{\text {nd }}$ order polynomial regression analyses. The highest correlation coefficient values were found when a $2^{\text {nd }}$ order polynomial regression was used. Equations representing the dependence of wheat grain yield on the organic matter in soil after wheat harvesting is shown via corresponding curves and the correlation coefficient values.

\section{Conclusion}

The calcareous soils are extensively deficient in nitrogen, phosphorus, zinc and organic matter, hence, application of fertilizers is considered imperative for increasing crop production. Mineral and/ or organic fertilizers play a significant role in boosting crop production on calcareous soils. It is desirable to reduce the use of mineral fertilizers, not more addition in using it and using new sources from organic fertilizers (compost) to reduce pollution of soil and ground water. The benefit is reflected on growing healthy plants, consequently better general health for human and animals.

\section{REFERENCES}

Adeniyan, O.A. and S.O. Ojeniyi, 2005. Effect of poultry manure, NPK 1515-15 and combination of their reduced levels on maize growth and soil chemical properties. Nigeria. J. of Soil Sci., 15: 34-41.

Agboola, A.A. and J.A. Omueti, 1982. Soil fertility problem and its management in tropical Africa. Paper presented at the International Institute of Tropical Agriculture, Ibadan, Nigeria, pp: 25.

AOAC, 1995. Official Methods of Analysis of the Association of Official Agricultural Chemists. $16^{\text {th }}$ Edn., AOAC, Washington DC., USA.

Asik, B.B., M.A. Turan, H. Celik and A.V. Katkat, 2009. Effect of humic substances on plant growth and mineral nutrients uptake of wheat (Triticum durum cv. Salihli) under conditions of salinity. Asian J. of Crop Sci., 1 (2): 87-95.

Ayodele, O.J. and S.O. Omotoso, 2008. Nutient management for maize production in soils of the Savannah Zone of South-Western Nigeria. International J. of Soil Sci., 3 (1): 20-27.

Ayoola, O.T. and E.A. Makinde, 2007. Complementary organic and inorganic fertilizer application: Influence on growth and yield of cassava/maize/melon intercrop with a relayed Cowpea. Aust. J. Basic Applied Sci., 1: 187-192;

Baloch, P.A., M. Moizuddin, M. Imam, B.A. Abro, J.A. Lund and A.H. Solangi, 2004. Effect of NPK fertilizers and farmyard manure on nut production of Coconut (Cocos Nucifera L.). Asian J. of Plant Sci., 3 (1): 91-93.

Bar-Tal, A., U. Yermiyahu, J. Beraud, M. Keinan and R. Rosenberg, 2004. Nitrogen, phosphorus and potassium uptake by wheat and their distribution in soil following successive, annual compost applications. J. Environ. Qual., 33: 1855-1865.

Fayoum J. Agric. Res. \& Dev., Vol. 26, No.2, July, 2012 
Bayu, W., N.F.G. Rethman, P.S. Hammes and G. Alemu, 2006. Effects of farmyard manure and inorganic fertilizers on sorghum growth, yield and nitrogen use in a semi-arid area of Ethiopia. J. Plant Nutri., 29: 391-407.

Belay, A., A.S. Classens, F.C. Wehner and J.M. De Beer, 2001. Influence of residual manure on selected nutrient elements and microbial composition of soil under long-term crop rotation. South Africa J. Plant Soil, 18: 1-6.

Celik, I., I. Ortas and S. Kilic, 2004. Effects of compost, mycorrhiza, manure and fertilizer on some physical properties of a Chromoxerert soil. Soil Till. Res. 78: $59-67$.

Chapman, H.D. and P.F. Pratt, 1961. Methods of Analysis for Soils, Plants and Waters. University of California, USA., pp: 1-309.

Cottenie, A., M. Verloo, L. Kiekens, G. Velghe and R. Camerlynck, 1982. Chemical Analysis of Plants and Soils. Laboratory of Analytical and Agrochemistry, State University-Ghent, Belgium

Fateh, E., M.R. Chaichi, E.S., Ashorabadi, D. Mazaheri, A.A. Jafari and Z. Rengel, 2009. Effect of organic and chemical fertilizers on forage yield and quality of Globe Artichoke (Cynara scolymus L.). Asian J. of Crop Sci., 1 (1): 40-48.

Jimenez, M.P., A. Horra, L. Pruzzo and M.R. Palma, 2002. Soil quality: A new index based on microbiological and biochemical parameters. Biol. Fertil. Soils, 35 : 302-306.

Kononova, M.M., 1966. Soil Organic Matter. Pergamon Press, Oxford, London, Edinburgh, New York, USA.

Korim, H.M. R.M. Fayed, M.A. Abu Sinna and A.E.A. Shiref, 2009. Reducing the use of N-mineral fertilizers through adding compost, biofertilizers and their effect on some soil properties and maize or wheat yield. J. Agric., Sci. Mansoura Univ., 34: 9555-9574.

Lombin, L.G., J.A. Adepetu and K.A. Ayotade, 1991. Organic Fertilizer in the Nigerian Agriculture: Present and Future. FPDD, Abuja, pp: 146-162.

Makinde, E.A., A.A. Agboola and F.I. Oluwatoyinbo, 2001. The effects of organic and inorganic fertilizers on the growth and yield of maize in a maize/melon intercrop. Moor J. Agric. Res., 2: 15-20.

Markus, D.K., J.P. Mckinnon and A.F. Buccafuri, 1982. Automated Analysis of Nitrite, Nitrite and Ammonium Nitrogen in Soils. New Jersey Agric. Exp. Stn. Publication, 84, New Jersey, USA.

Nardi, S.,F. Morari, A.Berti, M. Tosoni and L. Giardini, 2004. Soil organic matter properties after 40 years of different use of organic and minerals fertilizers. Eur.J.Agronomy, 21:357-367.

Prasad, B. and S.K. Sinha, 2000. Long-Term Effects of Fertilizers and Organic Manures on Crop Yield, Nutrient, Balance and Soil Properties in Rice-Wheat Cropping System in Bihar. in Long-Term Soil Fertility Experiments in Rice-Wheat Cropping Systems (Abrol, I.P., K.F. Bronson, J.M. Duxbury and R.K. Gupta (Eds.)., Rice-Wheat Consortium, Rajendra Agricultural University, Bihar, India, pp: 105-119.

Rajput, M.I., Z.A. Soomro and S.A. Siddiqui, 2004. Evaluation of bread wheat on different fertilizer level. Asian J. of Plant Sci., 3 (1): 143-144.

Rehman, S., S.K. Khalil, F. Muhammad, A. Rehman and A.Z. Khan, 2010. Phenology, leaf area index and grain yield of rainfed wheat influenced by organic and inorganic fertilizer. Pak. J. Bot., 42: 3671-3685.

SAS, 1994. SAS/STAT Users Guide: Statistics. Ver. $6.04,4^{\text {th }}$ Ed., SAS Institute Inc., Cary, NC., USA.

Seifritz, W., 1982. Alternative and renewable sources of energy in optimizing yields: The Role of Fertilizers. Proceedings of the $12^{\text {th }}$ IPI Congress, June, Germany, pp: 153-163

Fayoum J. Agric. Res. \& Dev., Vol. 26, No.2, July, 2012 
Shah, A., M. Shafi, J. Bakht, W. Mohammad and M. Shah, 2010. Effect of integrated use of nitrogen on yield and $\mathrm{N}$ uptake of maize crop. Pak. J. Bot., 42: 3633-3638.

Shah, S.A., S.M. Shah, W. Mohammad, M. Shafi and H. Nawaz, 2009. N uptake and yield of wheat as influenced by integrated use of organic and mineral nitrogen. Int. J. Plant Prod., 3: 45-56.

Sharma, A.R. and B.N. Mittra, 1991. Effect of different rates of application of organic and nitrogen fertilizers in a rice-based cropping system. Journal of Agricultural Science (Cambridge), 117: 313-318.

Shawer, S.S.A., 2003. Crop response to different fertilization programs in newly reclaimed soil. M.Sc. Thesis, Faculty of Agriculture, Al-Azhar University, Cairo, Egypt.

Shepherd, M.A., 1993. Measurement of soil mineral nitrogen to predict the response of winter wheat to fertilizer nitrogen after applications of organic manures or after ploughed out grass. J. Agric. Sci. Cambridge, 121:223-231.

Singh, C.M., P.K. Sharma, P. Kishor, P.K. Mishra, A.P. Singh, R. Verma and P. Raha, 2011. Impact of integrated nutrient management on growth, yield and nutrient uptake by wheat (Triticum aestivum L.). Asian J. of Agri. Res., 5 (1): 76-82.

Snedecor, G.W. and W.G. Cochran, 1976. Statically Methods. "6 ${ }^{\text {th }}$ ed., lwa State University Press. lowa, USA.

Soltanpour, P.N. and A.P. Schwab, 1991. Determination of nutrient availability element toxicity by AB-DTPA. Soil Test ICPS Adv. Soil Sci., 16: $165-190$.

Tisdale, S.L., W.L. Nelson and J.O. Beatoon, 1985. Soil Fertility and Fertilizers. $4^{\text {th }}$ Edn., The MacMillian Co., New York, USA., ISBN-13: 9780024208309,. pp: 512-513

Titiloye, E.O., 1982. The Chemical composition of different sources of organic wastes and their effects on growth and yield of maize (Zea maize L.) Ph.D. Thesis, University of Ibadan, Nigeria, pp: 316.

Tripathi, B.P. and J.K. Tuladhar, 2001. Sustaining wheat productivity and maintaining soil fertility in maize-wheat system. Nepal Agric. Res. J., Vol. 4 \& 5, 31-36.

Trono, Jr. G.C., 1986. Seaweed Culture in the Asia-Pacific Region. Regional Office for the Asia and the Pacific (RAPA), FAO of the United Nation, Bangkok, Thailand.

Weil, R.R. and F. Magdoff, 2004. Significance of Soil Organic Matter to Soil Quality and Health. In: Soil Organic Matter in Sustainable Agriculture, Magdoff, F. and R.R. Weil (Eds.). CRC Press, Boca Raton, FL, USA, pp. $1-43$.

Yassen, A.A., S.M. Khaled and M.Z. Sahar, 2010. Response of wheat to different rates and ratios of organic residues on yield and chemical composition under two types of soil. J. Am. Sci., 6(12): 858-864.

Zhang, Z.H., H.X. Song;Q. Liu, X.M. Rong; J.W. Peng, G.X. Xie and Y.P. Zhang, 2009. Study on differences of nitrogen efficiency and nitrogen response in different Oilseed Rape (Brassica napus L.) varieties. Asia Journal of Crop Science, 1 (2): 105-112.

Fayoum J. Agric. Res. \& Dev., Vol. 26, No.2, July, 2012 
Abd El-Aal, et al.,

تقييم إضافة الأسمدة العضوية وغير العضوية على انتاج الأرة والقمح في الأراضي الجيرية

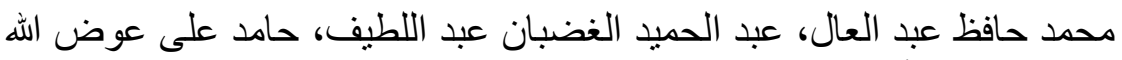

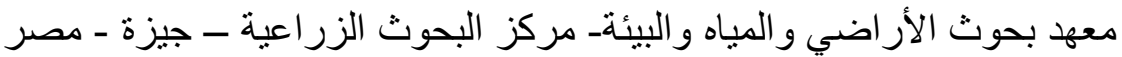

أجريت تجربة حقلية في محطة البحوث الزر اعية بالنوباريـة خـلال موسمين متتابعين

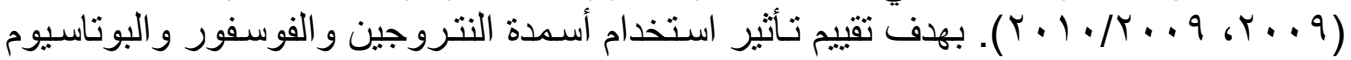

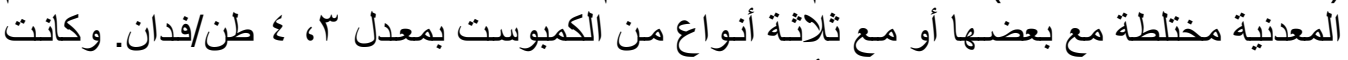

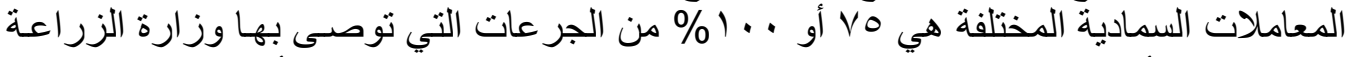

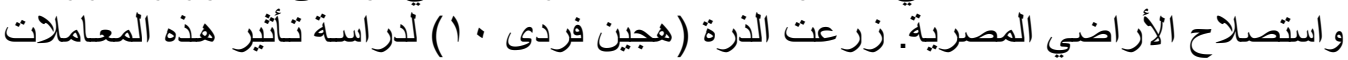

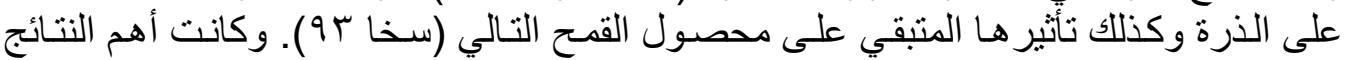

أن معدل . . 1\% من مخلوط السماد المعدني والكمبوست قد أعطى أعلى أعلى محصول هي:

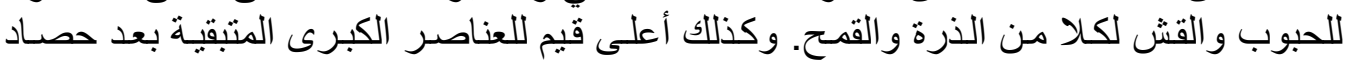

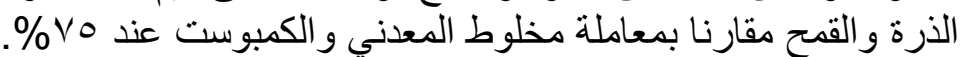
وبصفة عامة فإن .1\% من الأسمدة المعدنية فقط قد سجلت قيم اكبر لجميع القياسـات

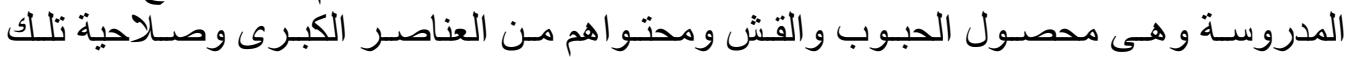

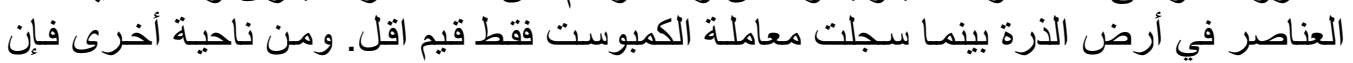

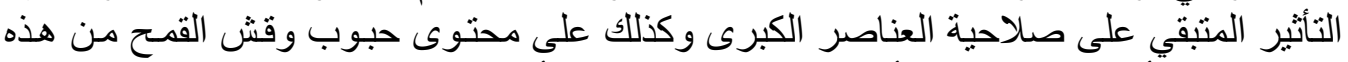

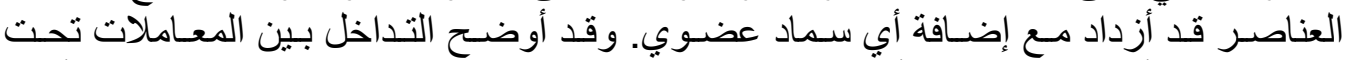

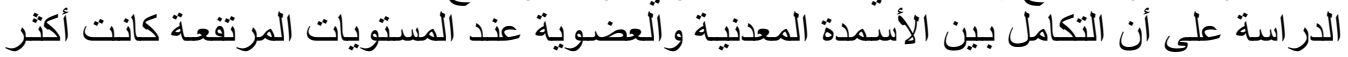

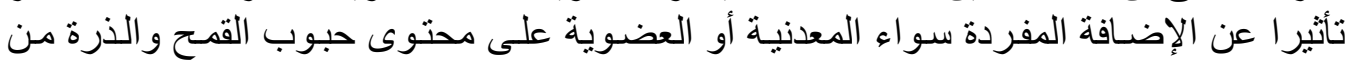

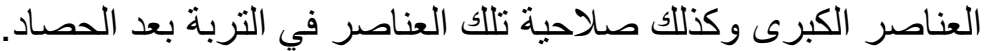

Fayoum J. Agric. Res. \& Dev., Vol. 26, No.2, July, 2012 